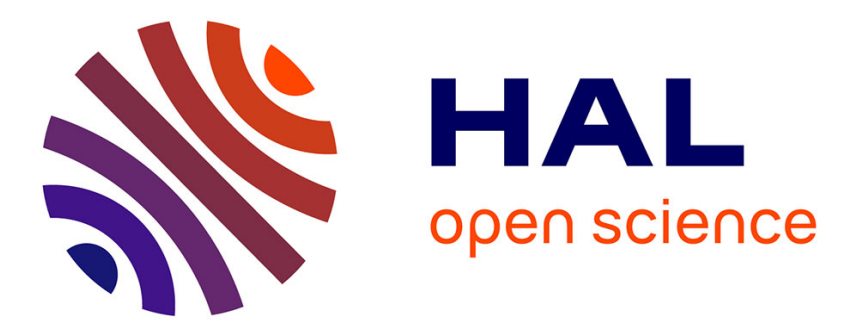

\title{
Botrytis cinerea spore balance of a greenhouse rose crop
} Thierry Boulard, Marie Chave, Hicham Fatnassi, Christine Poncet, Jean-Claude Roy

\section{To cite this version:}

Thierry Boulard, Marie Chave, Hicham Fatnassi, Christine Poncet, Jean-Claude Roy. Botrytis cinerea spore balance of a greenhouse rose crop. Agricultural and Forest Meteorology, 2008, 148 (3), pp.504511. 10.1016/j.agrformet.2007.11.014 . hal-02655374

\section{HAL Id: hal-02655374 https://hal.inrae.fr/hal-02655374}

Submitted on 29 May 2020

HAL is a multi-disciplinary open access archive for the deposit and dissemination of scientific research documents, whether they are published or not. The documents may come from teaching and research institutions in France or abroad, or from public or private research centers.
L'archive ouverte pluridisciplinaire HAL, est destinée au dépôt et à la diffusion de documents scientifiques de niveau recherche, publiés ou non, émanant des établissements d'enseignement et de recherche français ou étrangers, des laboratoires publics ou privés. 
BOTRYTIS CINEREA SPORE BALANCE OF A GREENHOUSE ROSE CROP

\author{
*T. Boulard ${ }^{1}$, M. Chave ${ }^{1}$, H. Fatnassi ${ }^{1}$, C. Poncet $^{1}$, J.C. Roy ${ }^{2}$ \\ ${ }^{1}$ INRA -URIH, 400, route des Chappes, BP 167, 06903 Sophia Antipolis, France \\ ${ }^{2}$ Institut FEMTO-ST, UMR 6174, Université de Franche-Comté, 2, Avenue Jean Moulin, \\ 90000 Belfort, France \\ *Corresponding author: boulard@sophia.inra.fr
}

\title{
Abstract
}

Fungal pathogens are among the most virulent bioagressors of protected crops. For sustainable plant production and to protect the crop against these airborne organisms one must determine their origin, i.e. whether they come from outside the greenhouse or are produced inside it.

We considered Botrytis cinerea spore concentration as a particular physical species which is transported by air in the same way as heat, $\mathrm{CO}_{2}$, water vapour or any tracer gas. We constructed a mass balance of the viable Botrytis spores on the whole greenhouse volume to assess the inside production of spores and their exchanges.

The different elements in the spore balance are considered and are determined experimentally:

- spore transfer into or out of the greenhouse is deduced from the difference between the inside and outside spore concentrations, measured by spore traps, multiplied by the wholegreenhouse ventilation rate;

- spore deposition on soil and crop and spore impaction on the plants is deduced from observations made using Petri dishes;

- inside spore production is the differential term deduced from the whole-greenhouse volume balance.

The first measurements and calculations have shown that the presence of insect-proof nets across the greenhouse openings strongly influences the spore balance, as the nets intercept the Botrytis cinerea spores proportionally to the nets' solidity. Based on wind tunnel experiments, the interception capacity of the nets was quantified and the whole model completed in consequence.

These results show the diurnal Botrytis spore balance over 3 - 4 week periods in the autumn and spring season for a young rose plantation. In agreement with visual observations 
1 of Botrytis cinerea sporulation within the greenhouse, it is shown that the origin of the inocula

2 is predominantly internal (2/3 in quantity). However, due to outside climate and greenhouse 3 opening, it can vary widely from one period to another, with a tendency to become 4 predominantly internal as the crop ages.

5 Keywords: greenhouse, air exchange rate, spore, balance, Botrytis cinerea, ventilation, rose 6 crop

\section{1-Introduction}

While biological control agents for most insect pests of greenhouse crops have been successfully applied to greenhouse crops in recent years, biological control of diseases is much less developed. Recent studies on the toxicological impact of greenhouse products (Anton et al., 2004) show that disease management still largely relies on chemicals. Most airborne fungal pathogens, particularly grey mould caused by Botrytis cinerea, are considered a major problem for greenhouse crop production.

Microclimatic parameters have long been recognised as key factors in the spread of fungal diseases and for greenhouse climate management for disease control. For example, open vents coupled with heating that renew the air and evacuate excess water vapour released by crop transpiration inside the greenhouse; greenhouses are an efficient way of controlling pests (Nicot and Baille, 1996; Jewett and Jarvis, 2001; Tantau and Lange, 2003; Körner and Challa, 2003).

However, while the prevailing climatic conditions are crucial for fungal development, it is also very important to control the level of fungal inocula. This aspect is generally poorly known and documented. To protect crops efficiently from airborne fungal spores, the origin of the inocula must be known - i.e. whether the spores come from outside the greenhouse or have been produced inside - and also their rate of production.

We have therefore adapted a classical physical method which has hitherto been chiefly used for performing mass or heat balances in finite volumes such as buildings and greenhouses, to perform a Botrytis cinerea spore balance of the protected crop and determine the origins of the inocula.

In this paper we present the study designed to perform this determination, and its experimental application to a real-scale rose greenhouse in the South of France, near Nice. 
Version définitive du manuscrit publié dans / Final version of the manuscript published in : Agricultural and Forest Meteorology, 2008, vol.148, no.3, DOI : 10.1016/j.agrformet.2007.11.014:

Botrytis cinerea spore concentration can be regarded as a particular physical species which is transported by air in the same way as heat, carbon dioxide or water vapour concentration. It can also be compared to any tracer gas, such as $\mathrm{N}_{2} 0$, which is traditionally used for measuring large-scale greenhouse air exchange rates (Boulard \& Draoui, 1995).

\section{2-1- Whole-greenhouse spore mass balance}

The tracer gas techniques used to measure ventilation flow rates are based on the mass balance of natural or artificial constituents of the whole-greenhouse air. For performing a greenhouse air mass balance, the choice of tracer gas is important: the gas should be inert, non-toxic and non-flammable, with a molecular weight close to the average weight of air components, and easy to measure at low concentrations. Many gases have been used, including $\mathrm{SF}_{6}, \mathrm{CH}_{4}, \mathrm{CO}_{2}, \mathrm{H}_{2}, \mathrm{~N}_{2} \mathrm{O}$, Argon 41 and Krypton 85. The two most frequently used for greenhouses are $\mathrm{CO}_{2}$ and $\mathrm{N}_{2} \mathrm{O}$, the latter being influenced neither by photosynthesis nor by plant respiration. However, water vapour $\left(\mathrm{H}_{2} \mathrm{O}\right)$ has also been used as a "natural" tracer gas (Demrati et al., 2001). Sherman (1990) has analysed tracer gas techniques for measuring ventilation in a single zone such as a greenhouse; he has shown that mixing problems can present a major source of potential error because the tracer gas must be uniformly mixed throughout the greenhouse. In these conditions Ducarme et al. (1994) estimate that the accuracy of an analysis by tracer gas is about $30 \%$ and that additional errors can also be caused by exfiltration air re-entering the measurement space at another location, or by changes in external conditions (wind speed, air temperature) during the measurement process.

Based on these approaches, we considered the finite volume of the greenhouse and performed its Botrytis cinerea spore balance according to equation (1), derived from the mass balance of the constituents of the whole-greenhouse air (Roy et al., 2002):

$$
V \frac{d c_{\text {in }}}{d t}=-G(t)\left(c_{\text {in }}(t)-c_{\text {out }}(t)\right)-D_{\text {in }}(t)+P_{\text {in }}(t)
$$

where $G$ is the ventilation flow rate, $V$ the greenhouse volume, $t$ the time, $c_{\text {in }}(t)$ and $c_{\text {out }}(t)$ the inside and outside concentrations of Botrytis cinerea spore's, $P_{i n}(\mathrm{t})\left(\mathrm{sp} \mathrm{s}^{-1}\right)$ is the spore's production rate inside and $D_{i n}(\mathrm{t})\left(\mathrm{sp} \mathrm{s}^{-1}\right)$ the inside spore deposition by sedimentation and impaction. One can assess the inside production of inocula $P_{i n}(t)$, measuring the inside and outside spore concentrations $c_{\text {in }}(t)$ and $c_{\text {out }}(t)\left(\mathrm{sp} \mathrm{m}^{-3}\right)$ together with the greenhouse air exchange rate $G(\mathrm{t})\left(\mathrm{m}^{3} \mathrm{~s}^{-1}\right)$, greenhouse volume $V\left(\mathrm{~m}^{3}\right)$, and spore deposition on crop and soil $D_{\text {in }}(t)\left(\mathrm{sp} \mathrm{s}^{-1}\right)$ : 
In this equation we make two crucial assumptions, (i) that the variables used in 2 equation (1) (i.e. $c_{\text {in }}(t), c_{\text {out }}(t), G, D_{\text {in }}$ and $P_{\text {in }}$ ) are discrete values corresponding to the mean of 3 the considered variable which vary from one time step to another and (ii) that all spores 4 deposited on the surfaces of soil or leaves remain there and do not return to the air.

Integrating equation (1) on time scale ( $t-\Delta t$ to $t)$ enables us to present this equation in a continuous and recursive form (2):

$$
c_{\text {in }}(t)=c_{\text {in }}(t-\Delta t) e^{-G(t) \Delta t / V}+c_{\text {out }}(t)\left(1-e^{-G(t) \Delta t / V}\right)+\left(\left(P_{\text {in }}(t)-D_{\text {in }}(t)\right) / G(t)\right)\left(1-e^{-G(t) \Delta t / V}\right)
$$

As the time scale, $\Delta t$, for experimental spore counting is long (from $8 \mathrm{~h}$ to $24 \mathrm{~h}$ ) the numerical value of $e^{-G(t) \Delta t / V}$ attached to the capacitive effect in equation (2) tends to 0 and becomes very small in relation to the other terms. Equation (2) then simplifies into equation (3):

$$
G(t)\left(c_{\text {in }}(t)-c_{\text {out }}(t)\right)-D_{\text {in }}(t)+P_{\text {in }}(t)=0
$$

Considering this equation and determining, for any time scale $\Delta t$ between 8 and 24 hours, the inside and outside spore concentrations $c_{\text {in }}(t)$ and $c_{\text {out }}(t)$ together with spore deposition $D_{i n}(t)$, and determining the air exchange rate $G(t)$ by means of a general ventilation model, we can deduce the rate of inside spore production $P_{i n}(t)$ for the period in question. A detailed diagram of the method is presented in Fig. 1.

However, Botrytis spores are solid particles with an average $10 \mu \mathrm{m}$ diameter, and can be intercepted by the solid matrix, i.e. the wires of the insect proof nets deployed on all the greenhouse vent openings, according to an equation which will be presented in section (4). The spore balance (equation (3)) must be modified in consequence to take into account a dimensionless spore interception value, $F(-)$ :

$$
F G(t)\left(c_{\text {in }}(t)-c_{\text {out }}(t)\right)-D_{\text {in }}(t)+P_{\text {in }}(t)=0
$$

\section{3-Experimental setup}

The experiments were carried out (Fig. 2) in three-spans of a four-span compartmented 28 plastic greenhouse (Multiclair 9600, Filclair, France). The main compartment $\left(576 \mathrm{~m}^{2}\right)$ was 
Version définitive du manuscrit publié dans / Final version of the manuscript published in : Agricultural and Forest Meteorology, 2008, vol.148, no.3, DOI : 10.1016/j.agrformet.2007.11.014:

1 occupied by a soilless rose plantation (3240 rose plants, $c v$ Magnum, Milva, Suella) planted in 2 spring (May 2003) in a new greenhouse erected just before, from December to March 2003. 3 Botrytis spore balances were systematically constructed in spring and autumn, for 2 to 4 4 weeks each time, from 2003 to 2005 (April 2003, October 2003, April 2004, November 2004 and May 2005), the first spore balance (April 2003) being performed before the rose crop was planted and all the others after.

In the greenhouse, natural ventilation was provided by means of roof vents and a side opening, both equipped with insect-proof nets (anti-Bemisia 10x20 meshes/cm, with a $0.2 \mathrm{~mm}$ thread diameter and 0.52 mesh solidity).

\section{$\underline{\text { 3-1-Physical measurements }}$}

The main exchange parameter $G$ was experimentally determined with the help of a general ventilation model given by equation (5), which considers both wind and stack effects together with the resistance of the insect-proof nets (which unfold on opening the vents) to air penetration (Boulard and Baille, 1995):

$$
G=A_{l}\left(\left(S_{o}+S_{f}\right) / 2\right)\left(2 g H_{c} / 4\left|T_{\text {out }}-T_{\text {in }}\right| /\left(T_{\text {out }}+273\right)+C_{w} V^{2}\right)^{0.5}
$$

where $A_{l}(-)$ is the overall discharge coefficient of the vent and insect-proof net, $C_{w}(-)$ is a wind effect coefficient on ventilation, $S_{o}$ and $S_{f}\left(\mathrm{~m}^{2}\right)$ are vent opening area and the corresponding leakage area, $H_{c}(\mathrm{~m})$ is an equivalent chimney height, $T_{\text {in }}$ and $T_{\text {out }}\left({ }^{\circ} \mathrm{C}\right)$ are inside and outside temperatures, and $V\left(\mathrm{~m} \mathrm{~s}^{-1}\right)$ is wind speed.

Wind speed and direction together with inside and outside temperature and humidity and vent opening (Fig. 3) area were systematically measured using the sensors of the greenhouse climate computer (L'ien, Vitrolles, 13, France) at a 1-minute frequency, stored and processed for a minimum average time of 15 minutes.

The model parameters $A_{l}$ and $C_{w}$ together with leakage area $S_{f}$, were determined in situ for this greenhouse by fitting the ventilation model to exchange rate measurements taken with tracer gas techniques, using $\mathrm{N}_{2} \mathrm{O}$ as tracer gas (Roy et al., 2002). A detailed description of the experimental study conducted to determine these parameters on this greenhouse can be found in Fatnassi et al. (2006) and more generally a survey of the values found in the literature can be found in Roy et al. (2002).

Knowing the specific greenhouse ventilation parameters $A_{l}, C_{w}$ and $S_{f}$ for the two main wind directions observed on the site and continuously measuring the inside and outside air temperatures $T_{\text {in }}$ and $T_{\text {out }}$ together with wind speed $V$ and vent opening area $S_{o}$, one can easily 
Version définitive du manuscrit publié dans / Final version of the manuscript published in : Agricultural and Forest Meteorology, 2008, vol.148, no.3, DOI : 10.1016/j.agrformet.2007.11.014:

1 deduce the air exchange rate $G$ from equation (5). In the April 2004 trial, additional inside air 2 speed measurements for studying the determinism of spores' terminal velocity were 3 performed, using omni-directional anemometers.

\section{3-2-Biological measurements:}

Inside $\left(\mathrm{c}_{\text {in }}\right)$ and outside $\left(\mathrm{c}_{\text {out }}\right)$ Botrytis cinerea spore concentrations were measured by means of two spore trap systems (Burkard Manufacturing Co Ltd, Rickmansworth, GB) with a $0.6 \mathrm{~m}^{3} \mathrm{~h}^{-1}$ flow rate, set up inside the greenhouse about $0.5 \mathrm{~m}$ above the crop canopy and outside, approximately $10 \mathrm{~m}$ away from the greenhouse. These spore traps were used continuously during the trials.

The total spore deposit in the greenhouse $\left(D_{i}\right)$ was estimated by means of 16 Petri dishes (Ø $9.5 \mathrm{~cm}$ for a surface of $7110^{-4} \mathrm{~m}^{2}$ ) placed horizontally above the rose bushes $(\approx 2 \mathrm{~m})$ to measure spore sedimentation on the crop canopy, together with 20 vertical Petri dishes oriented in the 4 cardinal directions to measure vertical impaction. Figure (3) shows schematically the horizontal position of the various biological and climate measurements inside and outside the greenhouse. The Botrytis spores captured from the air by the spore traps and Petri dishes were placed each day on a selective medium (Kerssies, 1990), incubated for 10 days and counted using a binocular microscope.

For comparing this indirect assessment of Botrytis cinerea sporulation inside the greenhouse with visual inspection, qualitative observation of Botrytis cinerea symptoms on rose buds and flowers and search for sporulating sources in the greenhouse were performed systematically on a weekly basis by the pathologists in charge of the experiment for all plants from 2003 to 2005 .

\section{3-3- Spore interception by the insect-proof net}

Spore interception by the insect-proof net was experimentally determined by wind tunnel experiments (Fig. 4). Spore interception by the insect-proof net was regarded as the ratio of the intercepted spores to the total number of spores injected into the wind tunnel:

The intercepted spore value (number of spores intercepted by the insect-proof net) was deduced from the measurements performed in the wind tunnel experiment, as follows: 
Version définitive du manuscrit publié dans / Final version of the manuscript published in : Agricultural and Forest Meteorology, 2008, vol.148, no.3, DOI : 10.1016/j.agrformet.2007.11.014:

Number of spores intercepted by the net $=$ Number of spores upstream from the net -

(Number of spores downstream from the net + Number of spores having sedimented in the wind tunnel)

where the number of spores upstream and downstream from the insect-proof net was measured using spore trap systems (Burkard Manufacturing Co Ltd, Rickmansworth, GB), and the number of sedimented spores was determined by means of Petri dishes.

These values were deduced from the mean of 3 wind tunnel tests lasting about 2 hours and performed with an air speed of $1.5 \mathrm{~m} \mathrm{~s}^{-1}$.

\section{4-Results and discussion}

Greenhouse spore balance and analysis of the principle spore characteristics are based on data recorded in 5 trials lasting between 3 and 4 weeks in April 2003, October 2003, April and November 2004 and May 2005, on a diurnal (12h from 08:00 to 20:00) and nocturnal (12h from 20:00 to 08:00) and on a 24-hour basis (from 08:00 to 08:00).

\section{4-1- Determination of Botrytis spores' terminal velocity in greenhouse conditions}

Although the determination of the spores' terminal fall velocity $v_{t}$, is not essential for performing their balance, the experimental results were also exploited for deducing this value which gives interesting insights on the dynamics of inside spores' transfer.

Theoretically, in still air, all suspended spores fall with a constant and characteristic terminal fall velocity $v_{t}$, given by Stokes' law (Seinfeld \& Pendis, 1998) and depending on gravity $g$, spore radius $r_{p}$, density $\rho_{p}$, a slip correction factor $C_{c}$ and air viscosity $\mu\left(1.7210^{-4} \mathrm{~g}\right.$ $\left.\mathrm{cm}^{-1} \mathrm{~s}^{-1}\right)$ :

$$
v_{t}=\left(\left(2 r_{p}\right)^{2} \rho_{p} g C_{c}\right) / 18 \mu
$$

For an average Botrytis cinerea spore radius $r_{p}=5 \mu \mathrm{m}$ and density $\rho_{p}=1.1 \mathrm{~g} \mathrm{~cm}^{-3}$, one obtains $v_{t}=0.00368 \mathrm{~m} \mathrm{~s}^{-1}$.

This theoretical value must be compared with the experimental determination derived from a dimensional analysis indicating that the terminal velocity of Botrytis spores $\left(\mathrm{m} \mathrm{s}^{-1}\right)$ results from the ratio of inside spore deposition $D_{i}\left(\mathrm{sp} \mathrm{m}^{-2} \mathrm{~s}^{-1}\right)$ to inside spore concentration $C_{i}(\mathrm{sp} \mathrm{m}$ ${ }^{3}$ ). In the experiments, $D_{i}$ was measured by means of the horizontal Petri dishes and $C_{i}$ by the Burkard spore traps, as described above. 
Version définitive du manuscrit publié dans / Final version of the manuscript published in : Agricultural and Forest Meteorology, 2008, vol.148, no.3, DOI : 10.1016/j.agrformet.2007.11.014:

$$
v_{t}=D_{i} / C_{i}
$$

2

3 For one month in April 2004 (days 104 to 134) one finds an average terminal velocity of $40.341 \mathrm{~cm} \mathrm{~s}^{-1}$ with a standard deviation of $0.11 \mathrm{~cm} \mathrm{~s}^{-1}$. This value is close to the theoretical 5 value of $0.368 \mathrm{~cm} \mathrm{~s}^{-1}$ deduced from Stokes' law (equation 8 ) for the average Botrytis cinerea spore diameter and density given above. This value is also within the range $\left[0.22\right.$ to $0.45 \mathrm{~cm} \mathrm{~s}^{-}$ ${ }^{1}$ ] experimentally determined by Gregory (1973) for Botrytis cinerea spores.

\section{4-2- Spore balance calculations}

\section{Spore interception by the insect-proof net}

Using the wind tunnel we were able to determine an average value for spore interception by our insect-proof net of $F=0.57$. This value is very close to the nets' mesh solidity (i.e. 0.52) and suggests that, as a first approximation, spore interception is directly proportional to the solidity of the net. However, this experimental value can also be compared with an empirical expression of $F$ calculated by Aylor and Ferrandino (1985) and pertaining to cylinders and ribbons, the threads of the insect-proof nets being regarded as cylinders:

$$
F=0.86 /\left(1+0.442 S_{t}^{-1.967}\right)
$$

With $\mathrm{S}_{\mathrm{t}}=2.085$, the Stokes number of the Botrytis spores computed for a $10 \mu \mathrm{m}$ spore diameter (Jarvis, 1977) and an average thread Ø of $200 \mu \mathrm{m}$ for the insect-proof net, one finds $F=0.78$. Although this value is higher than the experimental one $(0.57)$, the two values are not contradictory because the calculated value $(0.78)$ assumes that all intercepted spores 
Version définitive du manuscrit publié dans / Final version of the manuscript published in : Agricultural and Forest Meteorology, 2008, vol.148, no.3, DOI : 10.1016/j.agrformet.2007.11.014:

1 remain on the net threads, whereas the measured value takes into account only those

2 intercepted spores that actually do remain and are not re-circulated. Finding an experimental 3 value lower than the theoretical one is consistent with reality. We therefore used the 4 experimental value of $\mathrm{F}(0.57)$ for the spore balance calculation.

\section{Whole-greenhouse Botrytis spore balance}

Figures 6 ( $a$ and $b$ ) show examples of the daily (24-hours) time series of the main terms of the spore balance - exchange with the outside $\left(F G\left(C_{e^{-}}-C_{i}\right)\right)$, spore deposition $\left(D_{i} \Delta t\right)$, and spore production $\left(P_{i} \Delta t\right)$ - for the April 2004 and May 2005 trials.

For the April 2004 trial, which lasted 29 days, the spore production was always positive or nil, except during 3 days when a small negative value was observed. As already said, a negative spore production makes no sense either biologically or physically and is probably due to errors or imprecision in the balance setup. It is the case for example, when the difference $\left(C_{e}-C_{i}\right)$ is weak, as in April 2003 and when consequently the sign of this difference can change because of small imprecision's in the measurements of $C_{e}$ or $C_{i}$.

As the rose crop gets older, as for the May 2005 trial (Figure 6 b), spore production increases substantially and becomes systematically positive (export of spores due to an internal production), as indicated by the negative value of the transfer term $F G\left(C_{e^{-}} C_{i}\right) \Delta t$ during about half that period. For the same trials, Table 1 gives the average values of the different terms of the balance for measurement periods both before the rose crop was planted (April 2003) and after (April 2004 and May 2005) and Table 2 summarizes the statistical values for the different terms of the balance corresponding to measurements performed after the rose crop was planted (October 2003, April 2004, November 2004 and May 2005).

The spore concentration difference between inside and outside $\left(C_{e^{-}} C_{i}\right)$ can vary widely from one period to another with, for example, an inside concentration three times lower than outside during the April 2004 trial $\left(0.8 \mathrm{sp} \mathrm{m}^{-3}\right.$ vs $\left.2.7 \mathrm{sp} \mathrm{m}^{-3}\right)$, whereas inside and outside concentrations are approximately the same during the April 2003 and May 2005 trials. Statistical analysis of the components of the Botrytis cinerea spore balance on a daily basis for the four trials performed after the rose crop was planted (Table 2) together with the time trend in spore concentrations (Fig. 7) show that, on average, the inside spore's concentration remains fairly stable $\left(0.8 \mathrm{sp} \mathrm{m}^{-3}\right.$, with a standard deviation $\left.=0.05 \mathrm{sp} \mathrm{m}^{-3}\right)$ throughout the trials, whereas the outside concentration varies widely (from $0.8 \mathrm{sp} \mathrm{m}^{-3}$ to $3 \mathrm{sp} \mathrm{m}^{-3}$, with a standard deviation=1 $\left.\mathrm{sp} \mathrm{m}^{-3}\right)$. On a daily basis, spore production $\left(P_{i} \Delta t\right)$ is equal to $11,176 \mathrm{sp}$ before 
Version définitive du manuscrit publié dans / Final version of the manuscript published in : Agricultural and Forest Meteorology, 2008, vol.148, no.3, DOI : 10.1016/j.agrformet.2007.11.014:

1 rose crop planting in April 2003 (Table 1) and reaches an average of 83,939 sp for the trials

2 performed after planting (Table 2). Overall, increasing inside spore production is observed as 3 the crop ages (Table 1).

$4 \quad$ Table 1 also shows that total spore deposition $D_{i}\left(\mathrm{sp} \mathrm{s}^{-1}\right)$ (impaction plus sedimentation) can vary widely, from $0.65 \mathrm{sp} \mathrm{s}^{-1}$ in April 2003, before the rose crop was planted, to $2.9 \mathrm{sp} \mathrm{s}^{-1}$ in May 2005. The caption of Table 2 indicates that impaction represents only $20 \%$ of the total spore deposit, the major deposition being on horizontal surfaces ( $80 \%$ of the total deposition). With these new figures in mind, one can discuss one of the major assumptions of this study which is recall in section 2: "all spores deposited on the surfaces of soil or leaves remain there and do not return to the air". One can then distinguish between the deposition on soil, ultimate horizontal surface, for which this assumption is true and the vertical deposition on leaves, buds and stems, which concerns only $20 \%$ of the total spore's deposition, and for which this assumption can still be discussed.

Total spore deposition depends not only on inside spore concentration $C_{i}$ but also on the inside air speed and leaf area index values for the part corresponding to impaction on the crop canopy. Figure 8 presents the measured time trends for spore deposition (impaction plus sedimentation) and for the whole-greenhouse air exchange rate. For the various trials, one can observe the similarity between the courses of spore deposition and greenhouse ventilation intensity. As shown by Wang et al. (1999) greenhouse ventilation is also proportional to inside air speed, consequently, on average we also have a fairly close correlation between inside spore deposition and inside air speed. A similar trend was already observed on a daily time scale for only sedimentation (Fig. 5) and is also confirmed for a period lasting between 3 and 4 weeks for sedimentation and impaction together.

On average, taking into account all four trials performed after the rose crop was planted (October 2003, April 2004, November 2004 and May 2005), two thirds of the spores deposited inside were also produced inside, one-third coming from outside. However, very wide variations can occur from one period to another, as between the April 2004 and May 2005 trials (Fig. 9), with a general tendency for an increasing inside production as the crop grows old.

\section{4-3- Comparison of spore balance results with observations of sporulation}

The crucial task of independently verifying spore production is hard to perform because quantitative sampling is almost impossible in a rose crop. Because of its saprophytic capacity Botrytis c. produces spores on small crop debris (detached petals, leaves, stems), 
Version définitive du manuscrit publié dans / Final version of the manuscript published in : Agricultural and Forest Meteorology, 2008, vol.148, no.3, DOI : 10.1016/j.agrformet.2007.11.014:

1 which are difficult to detect, and petal spotting, which appears post-harvest on rose flowers.

2 Consequently, there are few symptoms of infection that can be detected in the greenhouse.

Based on systematic observations performed weekly, the first Botrytis c. sporulation

4 was observed in July 2004 on plant debris but we cannot be sure that there was no 5 fructification before that time, as it is very difficult to detect spore production on crop debris 6 in a production scale greenhouse. Similarly, the first symptoms of petal flecking on rose 7 flowers in the greenhoouse were observed some time later, during the November 2004 trial. 8 These roses were sampled and the samples (33) were placed in humid chambers; $100 \%$ of 9 them gave fructifications.

10 Figure 10 summarizes the results of spore production (P) calculated from equation (4) with 11 the qualitative observations of spore production. It shows the increase in inside sporulation, 12 whereas the term of spore exchange with the outside can vary widely from one period to 13 another. When the level of inside sporulation is high the spore exchange term can even be 14 negative, indicating spore exportation, as in May 2005. More generally, there is an observable 15 coherence between the general tendency for increasing inside spore production as the crop ages, as revealed by the spore balance, and the observation of Botrytis $c$. sporulation and petal spotting which occur respectively three and seven months after the first detection of a substantial increase in inside spore production.

\section{5 - Conclusion}

Although some uncertainty still attaches to our results as applied on a daily basis, this first attempt to perform a Botrytis cinerea spore balance inside a rose greenhouse gives plausible results if we take the average values for the different terms of the balance for an entire measurement period, i.e. between 15 and 30 days, and compare these quantitative results with more qualitative results on Botrytis $c$. sporulation. On this time scale, the main value of the method is that it enables us to determine the origin and evolution of the inocula, and in particular to state whether they came from inside or outside the greenhouse. It also enables us to identify and analyse, even sometimes on a time scale shorter than several weeks, the factors influencing spore concentration inside the greenhouse, such as ventilation rate, outside concentration, spore production and spore deposition on the rose crop canopy, with other factors such as inside spore concentration, crop surface area and air speed. The study also stresses the possibility of analysing the evolution of Botrytis cinerea establishment in a perennial crop such as roses. 
Version définitive du manuscrit publié dans / Final version of the manuscript published in : Agricultural and Forest Meteorology, 2008, vol.148, no.3, DOI : 10.1016/j.agrformet.2007.11.014:

However, this method is based on one major assumption, i.e. that "all the Botrytis cinerea spores that grow on the Kerssies medium and are counted can also potentially grow on the rose crop and contribute to the rose crop's Botrytis balance". Of course this assumption requires further validation by complementary studies assessing the biodiversity of Botrytis cinerea strains (Chave et al., 2004). It will then be possible to exploit this approach for studying more systematically the determination by biotic and non-biotic factors of Botrytis cinerea spore production within the greenhouse, and to confirm our first assessment that the spores in the greenhouse come predominantly from the outside, at least when the rose crop is young. It would then be possible to analyse the consequences of these findings for fungal development and the crop's agronomic performance.

Acknowledgements: This study was partly supported by the 2004-2006 Franco-Korean specific agreement on the "Development of an aerodynamic model to study microclimate of tomato canopy and predict pathogenic spore transfer" conducted by INRA (France) and NIAE-RDA (Republic of Korea). Thanks are also addressed to the trainee's engineer or teacher Ms Fanny Girardot and Christine Nieto who have actively participated to the project.

\section{Literature cited}

Anton A., Castell F., Montero JI., Huijbregts M., 2004. Comparison of toxicological impacts of integrated and chemical pest management in Mediterranean greenhouses. Chemosphere 54, $1225-1235$.

Aylor, D.E.,Ferrandino, F.J., 1985. Rebound of pollen and spores during deposition on cylinders by inertial impaction. Atmos. Environ., 19 (5), 803-806.

Boulard T., Baille A., 1995. Modelling of air exchange rate in a greenhouse equipped with continuous roof vents. J. agri. Engng Res., 61, 37-48.

Boulard T., Draoui B., 1995. Natural ventilation of a greenhouse with continuous roof vents: measurements and data analysis. J. agri. Engng Res., 61, 27-36.

Chave M., Boulard T., Thomas C., Fatnassi, H.; Julien P., Poncet C., 2004. Integrated protection in a greenhouse rose crop: origins of contamination -an approach \& preliminary results. Acta Hort. 659, 309-313.

Demrati H., Boulard T., Bekkaoui A., Bouirden L., 2001. Natural ventilation and climatic performance of a large-scale banana greenhouse. J. agri. Engng Res. 80 (3), 261-271. 
1 Ducarme D., Vandaele L., Wouters P., 1994. Single sided ventilation: a comparison of the

2 measured air change rates with tracer gas and with the heat balance approach. Documentation 3 for BAG meeting on ventilation related aspects in Buildings. 26-35.

4 Fatnassi H., Boulard T., Poncet C., Chave M., 2006. Optimisation of Greenhouse Insect 5 Screening with Computational Fluid Dynamics, Biosystem Engineering, 93 (33), 301-312.

6 Gregory P.H., 1973. The microbiology of the Atmosphere. Leonard Hill Books, London, $7 \quad 377 \mathrm{pp}$.

8 Jarvis W.R., 1977. Botrytinia and Botrytis Species: Taxonomy, physiology and 9 pathenogenicity. Monograph $n^{\circ} 15$, Agriculture Canada.

10 Jewett T., Jarvis W., 2001. Management of the greenhouse climate in relation to disease 11 control: a review. Agronomie 21, 351-366.

12 Körner O., Challa H., 2003. Process based humidity control regime for greenhouse crops. 13 Computers \& electronics in Agriculture 39, 173-192.

14 Kerssies A., 1990. A selective medium for Botrytis cinerea in a spore-trap. Neth. J. Pl. Path. $1596,247-250$.

Nicot P., Baille A., 1996. Integrated control of Botrytis cinerea on greenhouse tomatoes. Aerial surface microbiology, edited by Morris et al., Plenum press, New York, 169-189. Roy J.C., Boulard T., Kittas C., Wang S., 2002. Convective and ventilation transfers in greenhouses, Part 1: The greenhouse considered as a perfectly stirred tank. Biosystem Engineering 83 (1), 1-20.

21 Sherman M. H., 1990. Tracer-gas techniques for measuring ventilation in a single zone. 22 Building and Environment, 25(4), 365-374.

23 Seinfeld J., Pandis S., 1998. Atmospheric chemistry \& physics: from air pollution to climate 24 change. John Willey \& sons, New York, 1326pp.

25 Tantau H.G., Lange D., 2003. Greenhouse climate control: an approach for integrated pest management. Computers \& Electronics in Agriculture, 00, 1-12.

\section{Meteorol., 96, 181-188.}




\section{Pంs\}}

Version définitive du manuscrit publié dans / Final version of the manuscript published in : Agricultural and Forest Meteorology, 2008, vol.148, no.3, DOI : 10.1016/j.agrformet.2007.11.014:

1 Tables:

2

3

\begin{tabular}{cccc}
\hline Variables & $\begin{array}{c}\text { April 2003 trial } \\
\text { Mean value }\end{array}$ & $\begin{array}{c}\text { April 2004 trial } \\
\text { Mean value }\end{array}$ & $\begin{array}{c}\text { May 2005 trial } \\
\text { Mean value }\end{array}$ \\
\hline$G\left(\mathrm{~m}^{3} \mathrm{~s}^{-1}\right)$ & & & \\
$C_{e}\left(\mathrm{sp} \mathrm{m}^{-3}\right)$ & 4.1 & 1.7 & 7.9 \\
$C_{i}\left(\mathrm{sp} \mathrm{m}^{-3}\right)$ & 0.8 & 2.7 & 0.8 \\
$D_{i}\left(\mathrm{sp} \mathrm{s}^{-1}\right)$ & 0.6 & 0.8 & 0.9 \\
$F G\left(C_{e}-C i\right) \Delta t(\mathrm{sp})$ & 0.6 & 1.9 & 2.9 \\
$D_{i} \Delta t(\mathrm{sp})$ & 30,017 & 104,197 & $-14,615$ \\
$P_{i} \Delta t(\mathrm{sp})$ & 43,418 & 160,231 & 249,713 \\
& 11,176 & 54,891 & 266,329 \\
\hline
\end{tabular}

Table 1: Components of the Botrytis cinerea spore balance on an average daily basis for 6 the April 2003 (10 days), April 2004 (30 days) and May 2005 (14 days) trials. 
Version définitive du manuscrit publié dans / Final version of the manuscript published in : Agricultural and Forest Meteorology, 2008, vol.148, no.3, DOI : 10.1016/j.agrformet.2007.11.014:

1

2

3
Average of the 4 trials

\begin{tabular}{ccccc}
\cline { 2 - 5 } Variables & Mean value & Minimum & Maximum & $\begin{array}{c}\text { Standard } \\
\text { deviation }\end{array}$ \\
\hline$G\left(\mathrm{~m}^{3} \mathrm{~s}^{-1}\right)$ & 2.4 & 0.4 & 7.9 & 3.1 \\
$C_{e}\left(\mathrm{sp} \mathrm{m}^{-3}\right)$ & 1.8 & 0.8 & 3.0 & 1.0 \\
$C_{i}\left(\mathrm{sp} \mathrm{m}^{-3}\right)$ & 0.85 & 0.8 & 0.9 & 0.05 \\
$D_{i}\left(\mathrm{sp} \mathrm{s}^{-1}\right)$ & 1.4 & 0.4 & 2.9 & 0.95 \\
$F G\left(C_{e}-C i\right) \Delta t(\mathrm{sp})$ & 35,853 & $-14,615$ & 22,359 & 45,000 \\
$D_{i} \Delta t(\mathrm{sp})$ & 122,083 & 37,857 & 249,713 & 80,876 \\
$P_{i} \Delta t(\mathrm{sp})$ & 85,939 & 14,308 & 266,329 & 96,776 \\
\hline
\end{tabular}

Table 2: Components of the Botrytis cinerea spore balance on an average daily basis for the four trials performed after the rose crop was planted (October 2003, April 2004, November 2004 and May 2005). On average the deposition on vertical surfaces due to impaction represents only $20 \%$ of the total horizontal $\left(D_{h}\right)$ plus vertical $\left(D_{v}\right)$ deposit. 


\section{Pంs\}}

Version définitive du manuscrit publié dans / Final version of the manuscript published in : Agricultural and Forest Meteorology, 2008, vol.148, no.3, DOI : 10.1016/j.agrformet.2007.11.014:

\section{$1 \quad$ Figures}

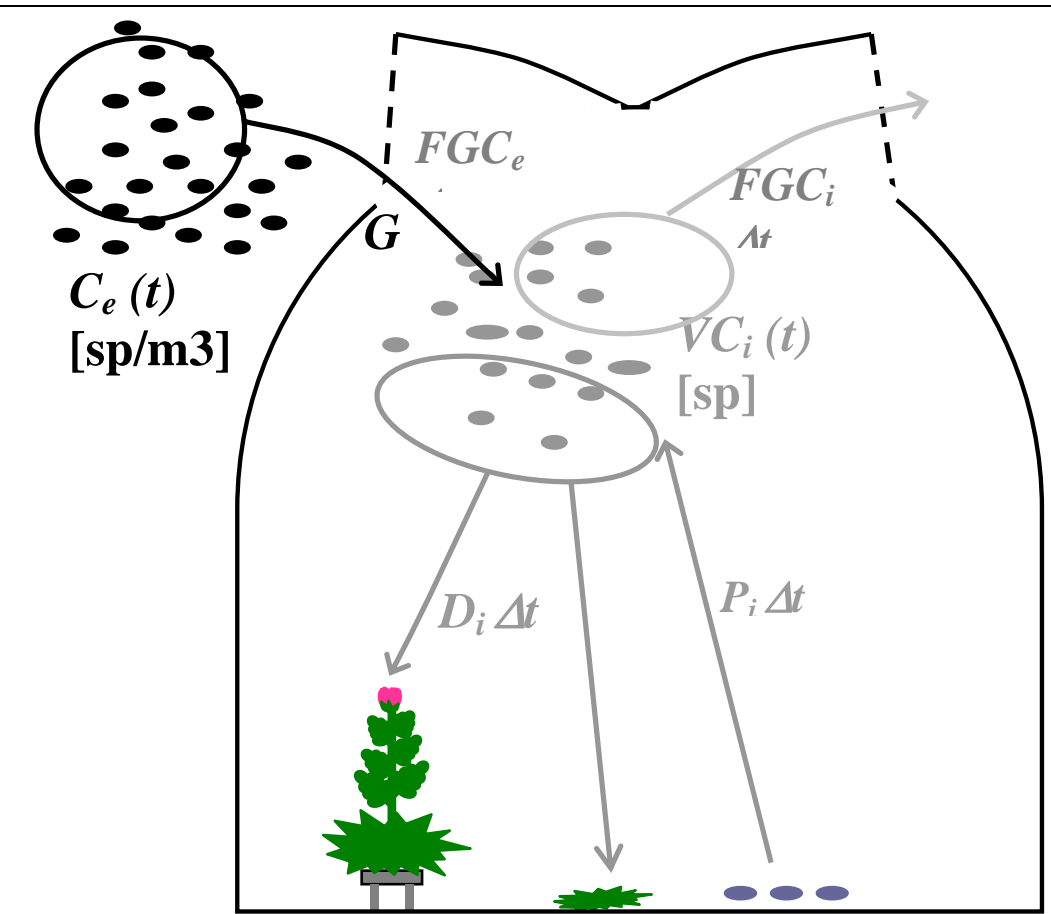

$\boldsymbol{C}_{\boldsymbol{e}}:$ B. cinerea spore concentration in outside air

$\boldsymbol{C}_{\boldsymbol{i}}:$ B. cinerea spore concentration in inside air

$\boldsymbol{P}_{\boldsymbol{i}}$ : Inside spore production $\boldsymbol{D}_{\boldsymbol{i}}$ : Spore deposition on greenhouse soil and on crop canopy $\boldsymbol{V}$ : Greenhouse volume $\boldsymbol{G}$ : Air exchange rate $\boldsymbol{F}$ : Spore interception by the net $\Delta t$ : Time space

Figure 1: Method for identifying the origin of Botrytis cinerea inocula using a spore balance 4 


\section{Pంs\}}

Version définitive du manuscrit publié dans / Final version of the manuscript published in : Agricultural and Forest Meteorology, 2008, vol.148, no.3, DOI : 10.1016/j.agrformet.2007.11.014:

1

$\mathbf{E}$

Roof vents with insect proof nets

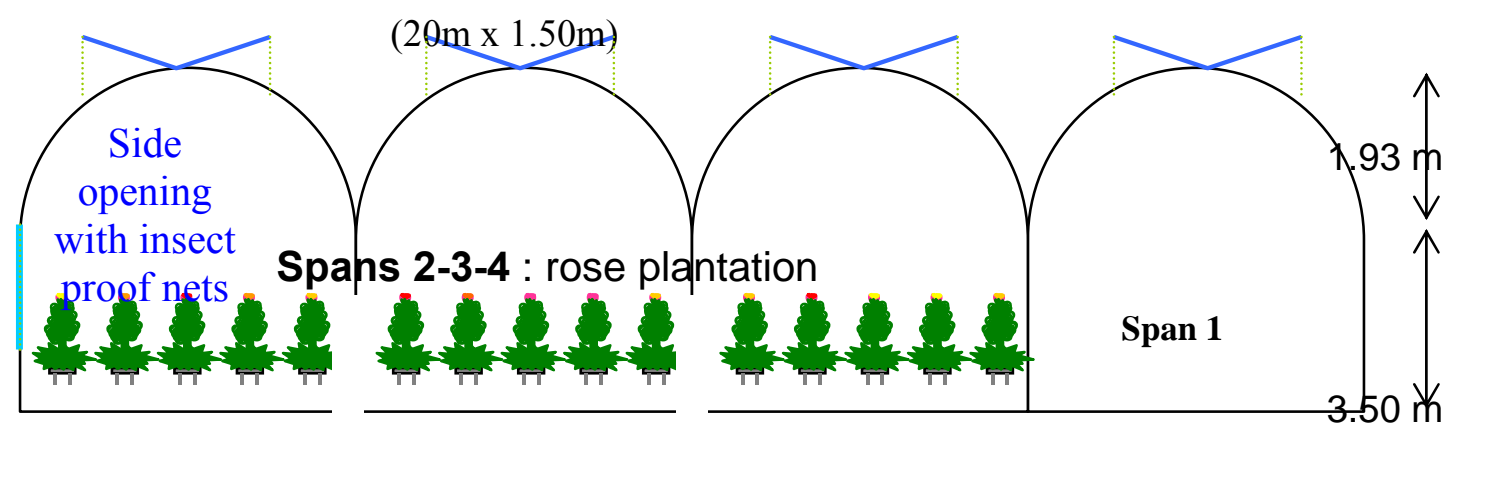

2 Figure 2: Transverse cross section of the $576 \mathrm{~m}^{2}$ experimental greenhouse. 
Version définitive du manuscrit publié dans / Final version of the manuscript published in : Agricultural and Forest Meteorology, 2008, vol.148, no.3, DOI : 10.1016/j.agrformet.2007.11.014:<smiles>CC(C)[AlH]</smiles>

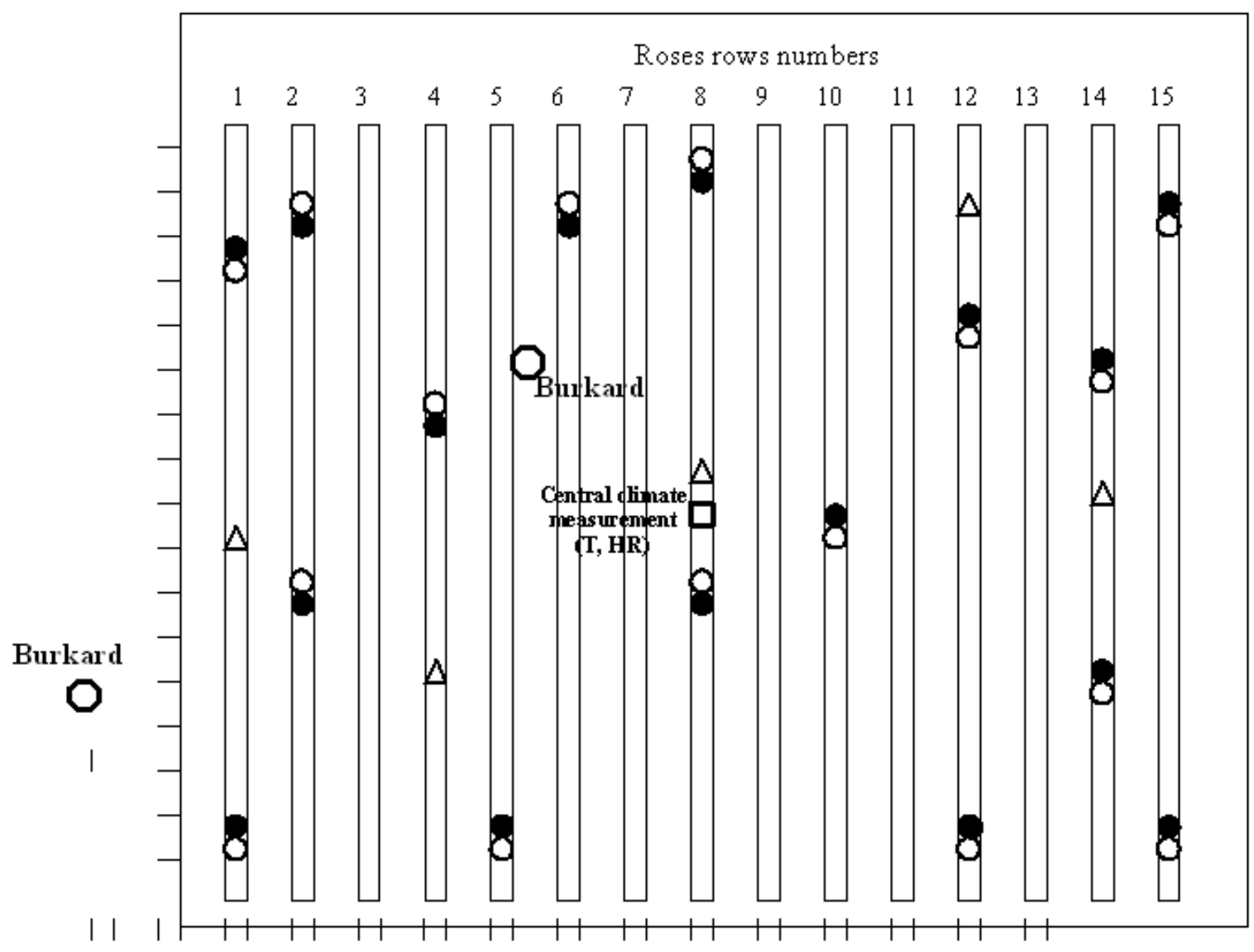

Figure 3: Plan of the greenhouse with positioning of the biological and climate measurements.

- Horizontal spore deposition traps using $90 \mathrm{~mm} ø$ Petri dishes with a Kerssies medium, placed at a height of $2.5 \mathrm{~m}$.

O Horizontal spore deposition traps using $90 \mathrm{~mm} ø$ Petri dishes with a Kerssies medium, placed just above soil level.

$\triangle$ Vertical spore impaction traps using $90 \mathrm{~mm} ø$ Petri dishes with a Kerssies medium,

placed at a height of $2.5 \mathrm{~m}$.)

Suction volumetric spore traps (Burkard)

口 Central greenhouse climate sensors (T, RH) using the greenhouse's climate computer devices (L'ien, Vitrolles, France)

Wind speed and direction were measured outside the greenhouse at $5.5 \mathrm{~m}$ high about 15 meters apart West of the greenhouse. 
Version définitive du manuscrit publié dans / Final version of the manuscript published in : Agricultural and Forest Meteorology, 2008, vol.148, no.3, DOI : 10.1016/j.agrformet.2007.11.014:

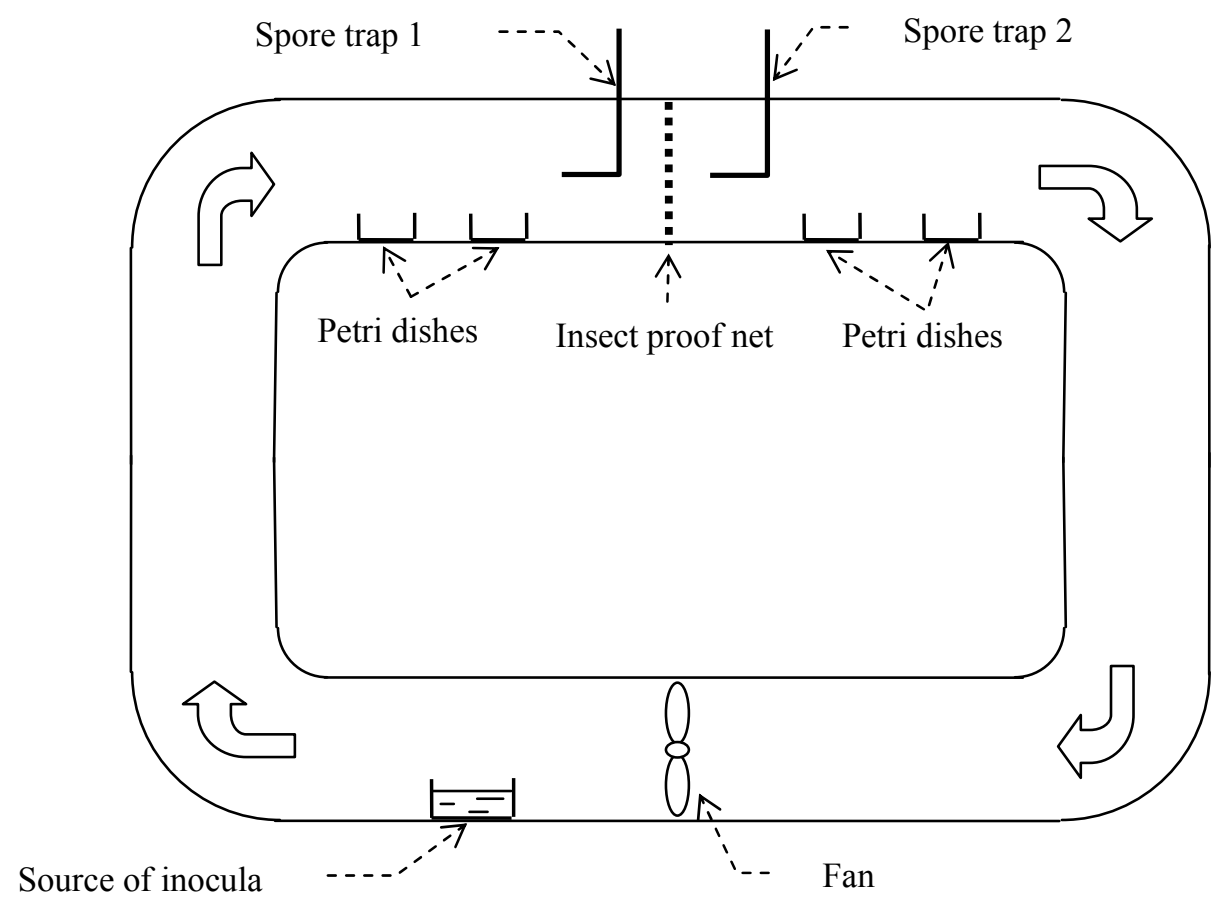

$4 \quad$ Figure 4: Sketch of the closed-loop wind tunnel experiment designed to determine spore 5 interception by the insect-proof net. 
Version définitive du manuscrit publié dans / Final version of the manuscript published in : Agricultural and Forest Meteorology, 2008, vol.148, no.3, DOI : 10.1016/j.agrformet.2007.11.014:

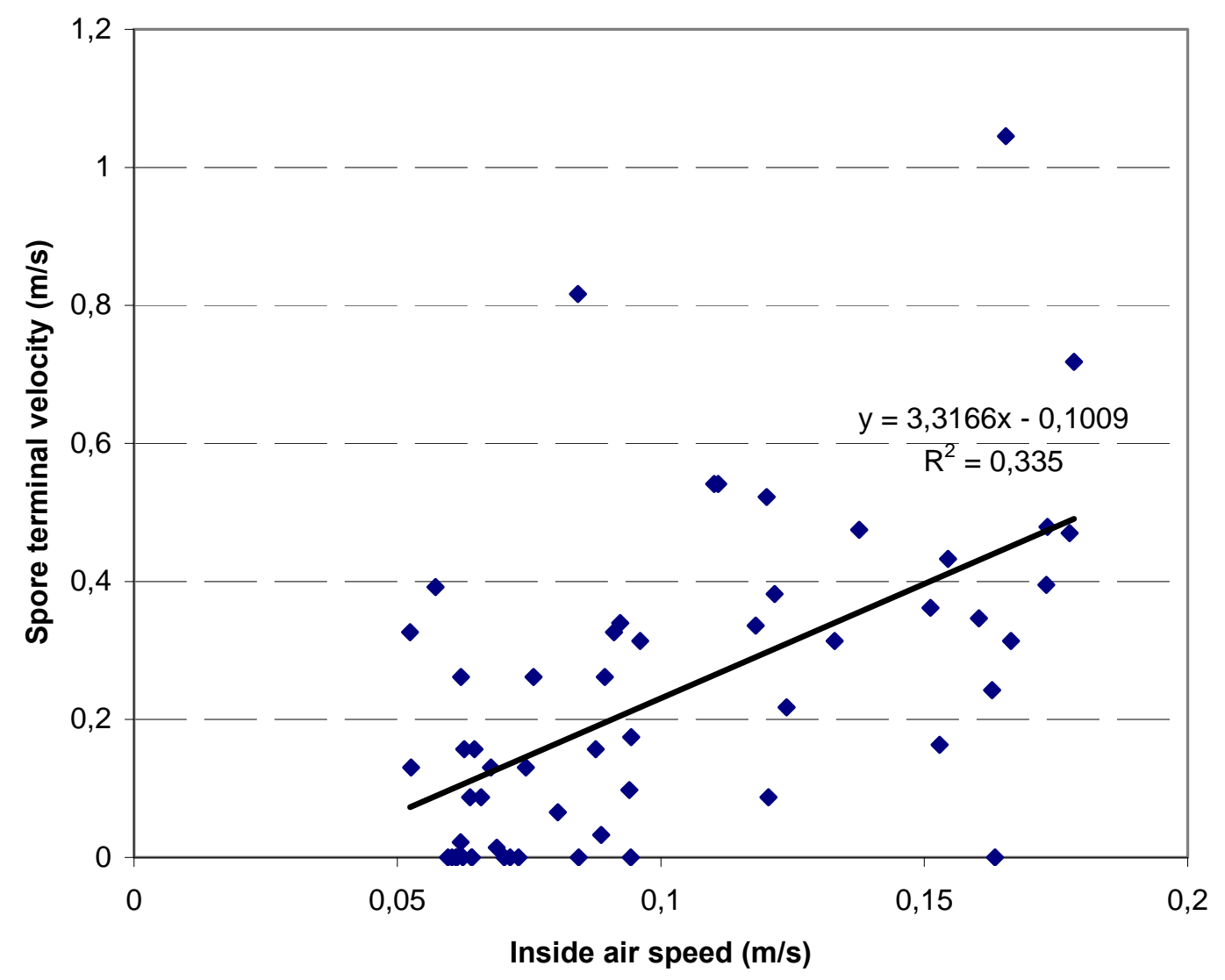

Figure 5: Experimental linear relation between average inside air speed recorded over a 12 hour period and calculated inside terminal velocity of spores computed for the same time span (April 2004 data). 
Version définitive du manuscrit publié dans / Final version of the manuscript published in : Agricultural and Forest Meteorology, 2008, vol.148, no.3, DOI : 10.1016/j.agrformet.2007.11.014:

a)

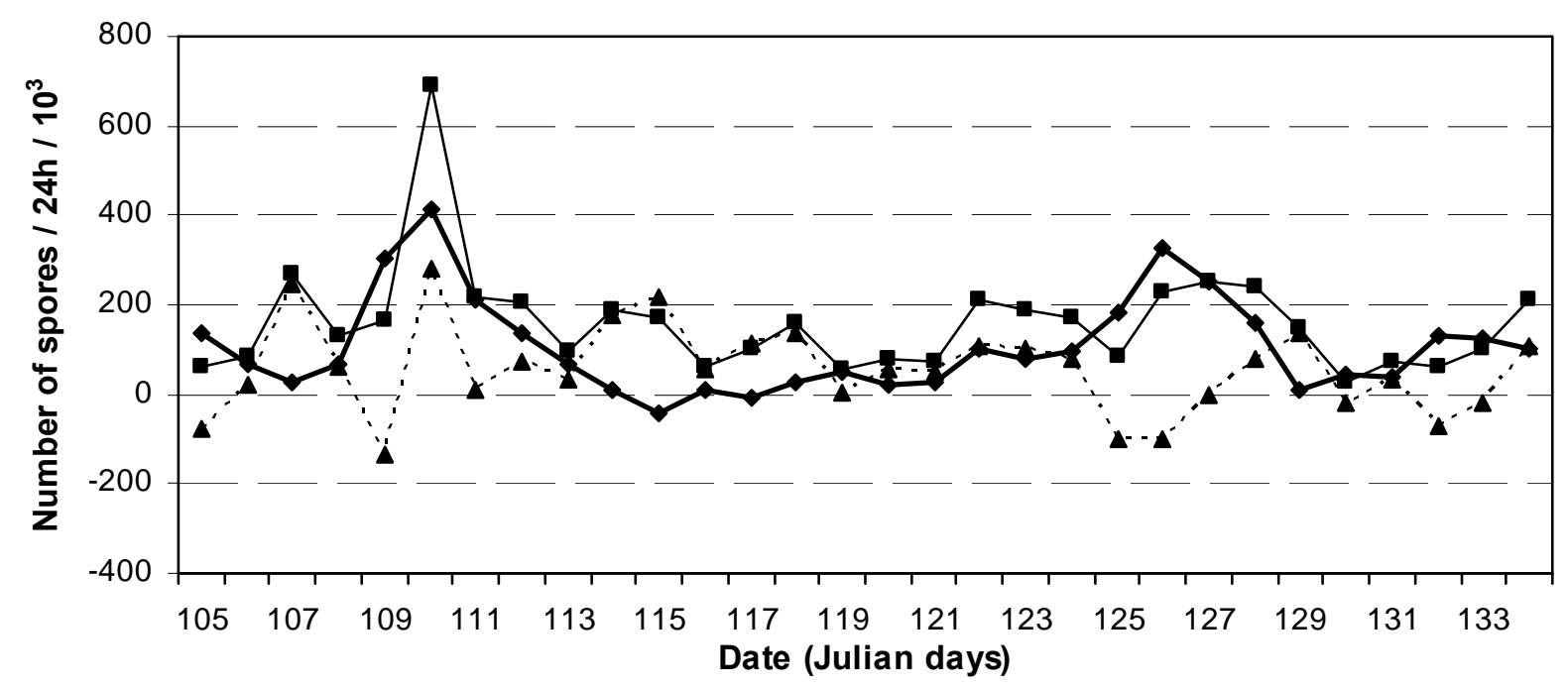

b)

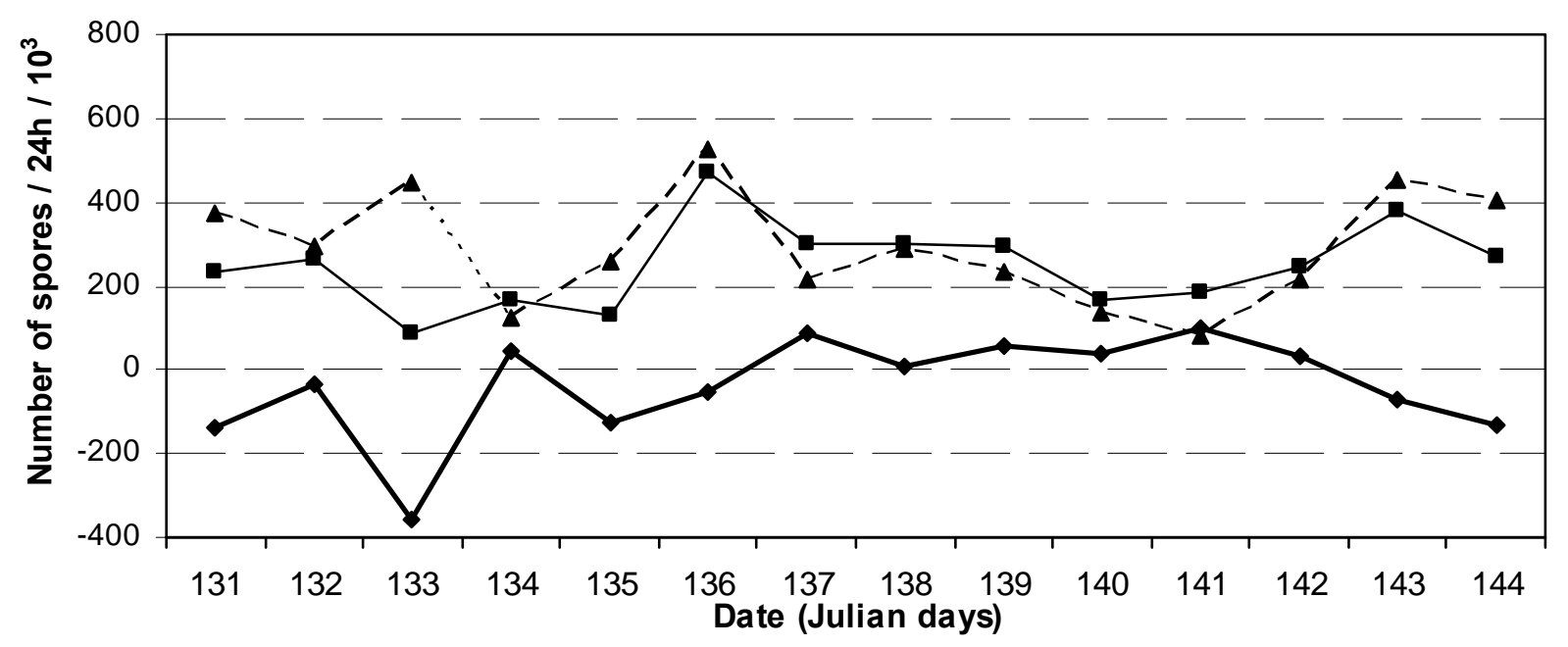

Figure 6: Time trends of the different components of the greenhouse rose Botrytis cinerea spore balance corrected for spore interception by the insect proof net $[\mathrm{FG}(\mathrm{Ce}-\mathrm{Ci})$ delta $\mathrm{t}$ :

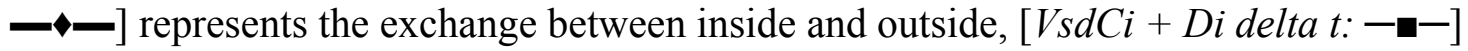
represents the inside variation due to deposit and air content variation, [Pi delta $t$--- $\boldsymbol{\Lambda}$---] represents the inside spores production; (a) data from the April 2004 trial; b) data from the May 2005 trial. 
Version définitive du manuscrit publié dans / Final version of the manuscript published in : Agricultural and Forest Meteorology, 2008, vol.148, no.3, DOI : 10.1016/j.agrformet.2007.11.014:

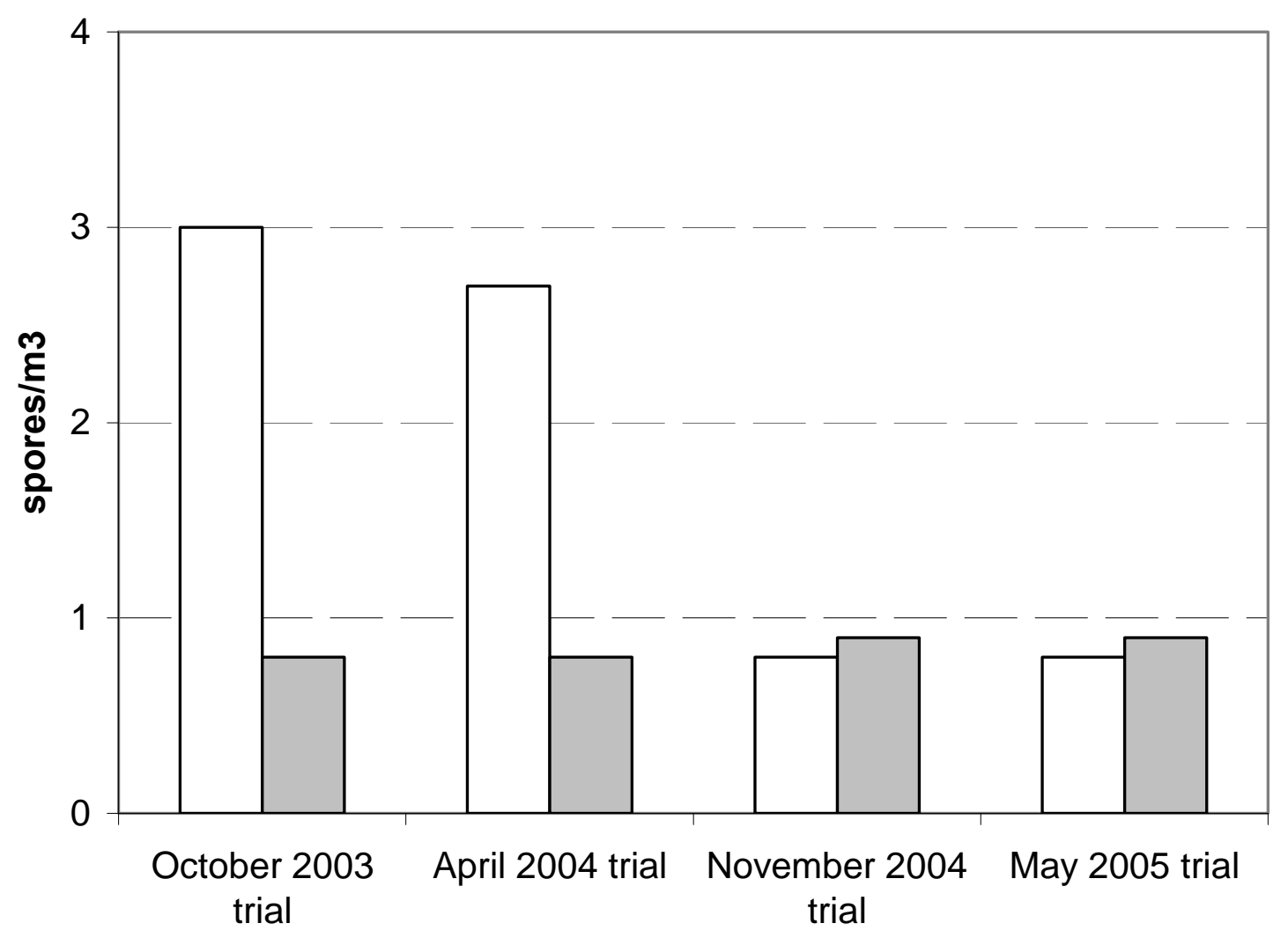

3 Figure 7: Average values for measured inside $\square$ and outside $\square$ spore concentrations for the 4 4 different trials (October 2003, April and November 2004 and May 2005). 


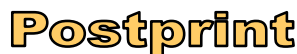

Version définitive du manuscrit publié dans / Final version of the manuscript published in : Agricultural and Forest Meteorology, 2008, vol.148, no.3, DOI : 10.1016/j.agrformet.2007.11.014:

1

2

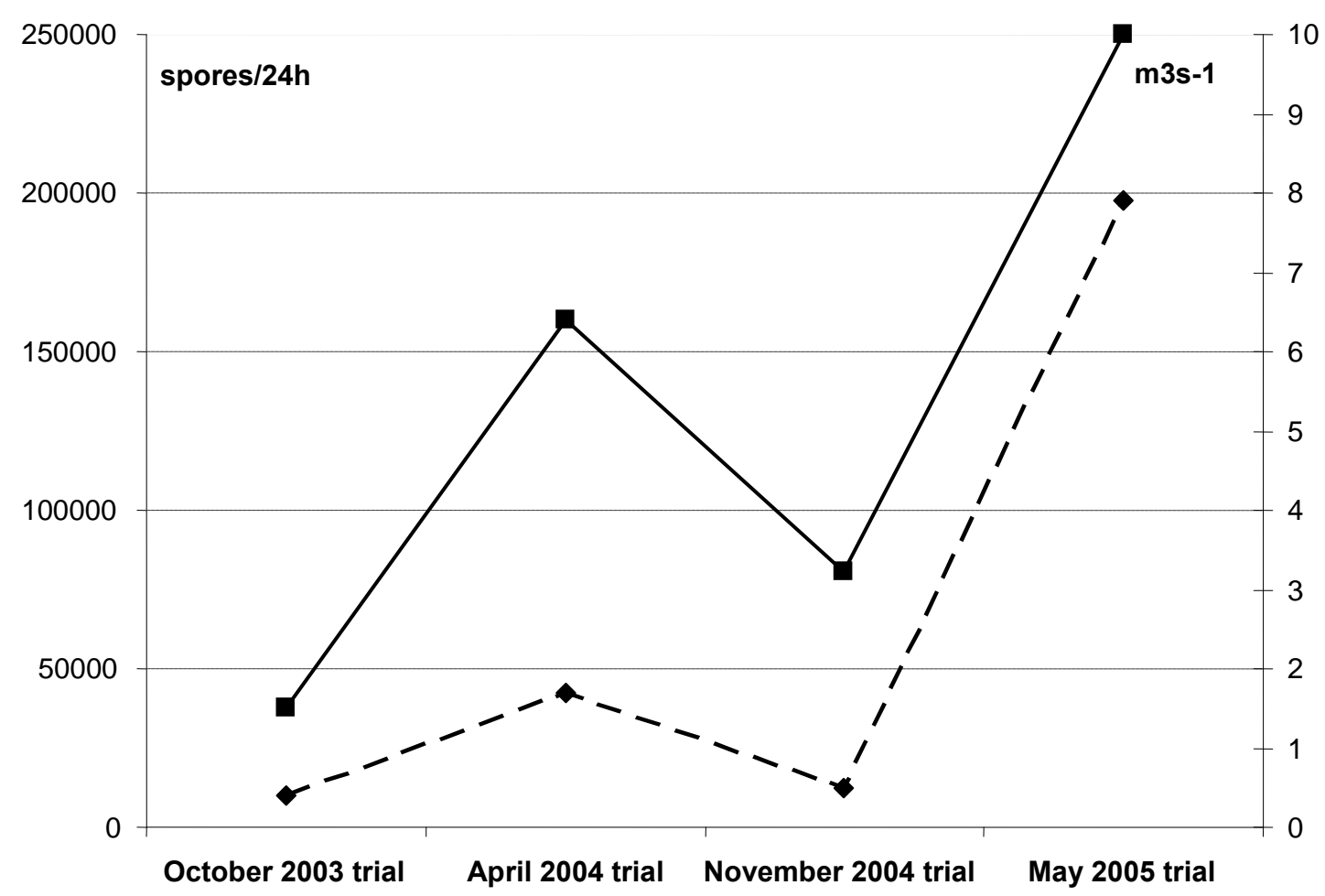

3

4 Figure 8: Evolution of average spore deposition, $V s d C i+$ Di delta $t$ (一), left axis), and 5 6 7 greenhouse ventilation rate, $G(-\downarrow-$, right axis) (October 2003, April and November 2004 and May 2005). 
Version définitive du manuscrit publié dans / Final version of the manuscript published in : Agricultural and Forest Meteorology, 2008, vol.148, no.3, DOI : 10.1016/j.agrformet.2007.11.014:

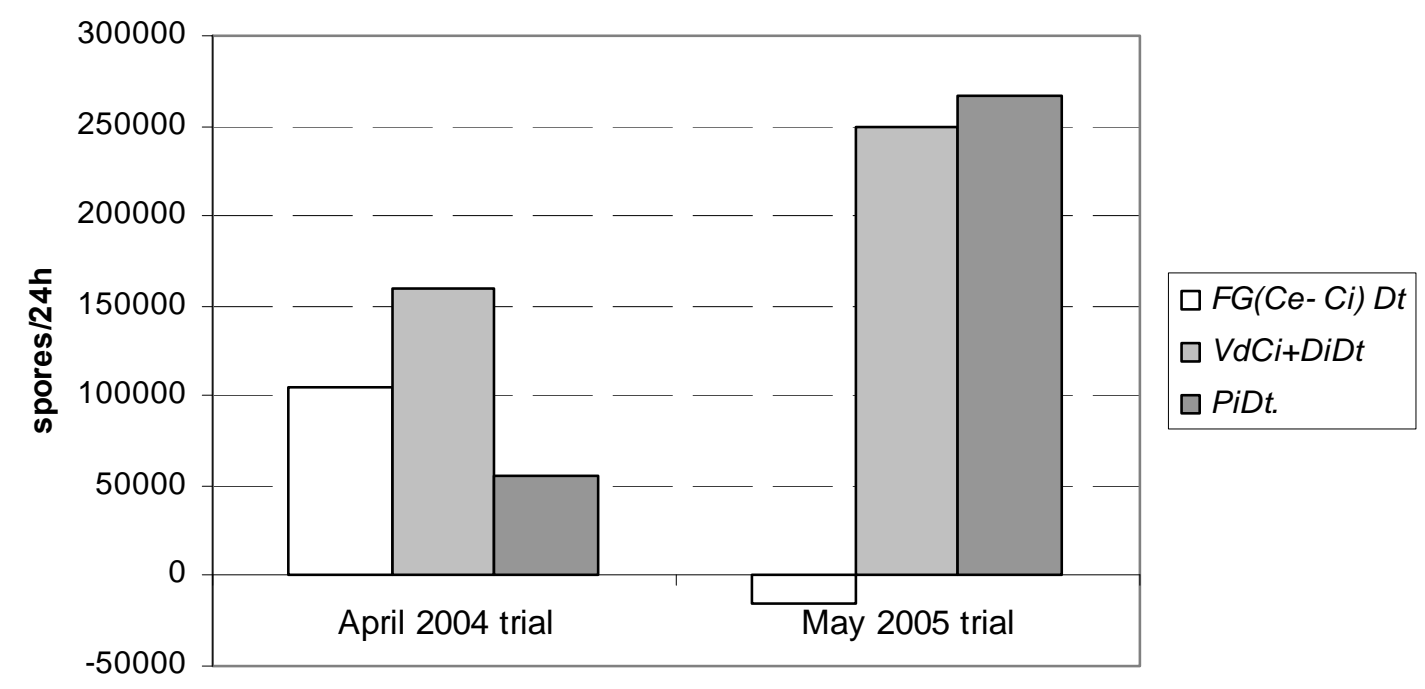

Figure 9: Average values of the different terms of the Botrytis cinerea spore balance for April 2004 and May 2005 trials.

4

5

6

7

8

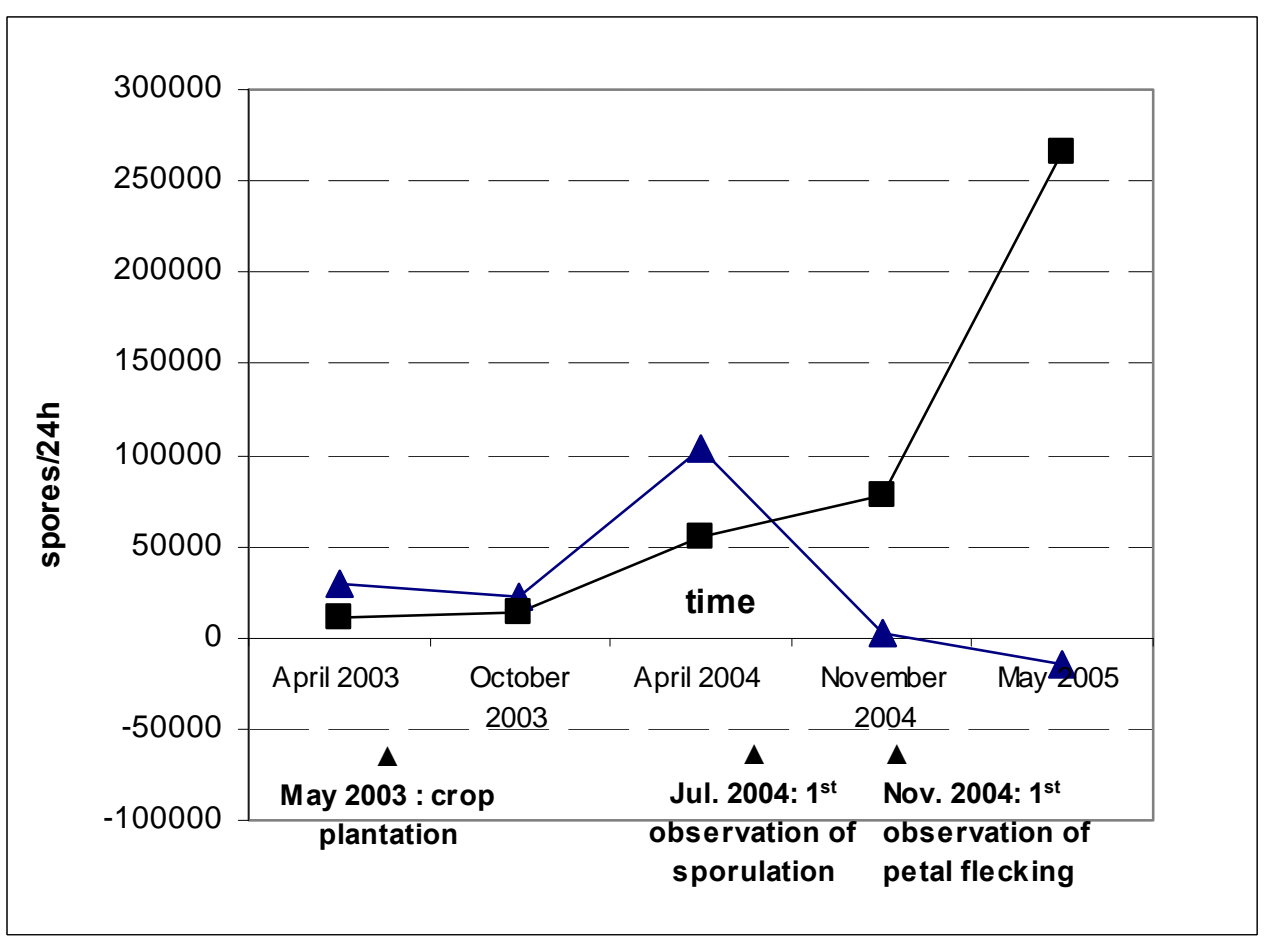

Figure 10: Time course of spore production [Pi $\Delta t:-\mathbf{-}-]$ and exchange between inside and outside $[F G(\mathrm{Ce}-\mathrm{Ci}) \Delta t:-\mathbf{\Delta}-]$ terms from April 2003 to May 2005 together with a recapitulative time schedule of the visual observations of Botrytis $c$. infestation in the greenhouse (in bold characters in the figure). 